\title{
Soil: a weapon for food security and climate change adaptation and mitigation
}

\section{Editorial}

The world has already been reported to has been affected by the extreme climatic conditions and facing greater challenge for feeding its teeming population against a backdrop of a changing climate and growing competition for land, water, labour and energy. It is critical to reducing greenhouse gas emissions by agriculture, presently estimated at $30 \%{ }^{1}$ Soil is the greatest non renewable resource or renewable only at human scale. Soils provide essential ecosystem services by providing food, feed, fibre and fuel for humans, harbouring biodiversity, filtering drinking water, sequestering carbon (C) etc. ${ }^{2}$ Judicious management practices of soil in agricultural, forest and grassland ecosystems can enhance sustainable soil health and thus results in sustainable food and environmental security. Sequestering carbon in soils in terrestrial ecosystems will help mitigation of an adaptation to global climate change. Carbon sequestration in soils can help mitigate global climate change. ${ }^{3}$ Enhanced soil organic matter content will strengthen nutrient cycling in soils for sustainable productivity in vulnerable soils to climate change across land use systems and in various problem soils like saline soils, acid sulphate soils, draught prone land etc. Biodiversity conservation, closely related to terrestrial and aquatic $\mathrm{C}$ sequestration. ${ }^{4}$ Soil ecosystem services can be economic, social and environmental which can extend from local to global. Soil erosion, fertility loss, salinity, acidification, compaction and the loss of carbon are natural processes that can be accelerated tremendously by excessive use of soil and inappropriate management practices.

Reduction of $\mathrm{CO}_{2}$ emissions is a global concern. Increasing net primary production through photosynthesis and trapping of part of it into stable humic substances and secondary carbonates can tremendously reduce global $\mathrm{CO}_{2}$ emissions. Increased soil organic $\mathrm{C}$ content, a store house of plant nutrients, can increase soil macro and micronutrient availability for plants through recycling of essential nutrients. For example, an increase in the soil organic $\mathrm{C}$ pool by $1 \times 10^{-}$ ${ }^{9} \mathrm{Pg} \mathrm{C} \mathrm{ha}^{-1}$ can increase wheat (Triticum aestivum) yield by 20 to $70 \mathrm{~kg}$ ha $^{-1}$, rice (Oryza sativa) yield by 10 to $50 \mathrm{~kg} \mathrm{ha}^{-1}$, corn yield by 30 to $300 \mathrm{~kg} \mathrm{ha}^{-1}$, and beans (Phaseolus vulgaris) yield by 10 to $20 \mathrm{~kg} \mathrm{ha}^{-1} .^{3}$ Adoption of improved soil management practices for improved soil quality is key to maintaining sustainable soil quality for adaptation to global climate change effects.

A holistic and system based approach to soil management as the engine for increasing productivity by increasing efficiency and making agriculture environmentally compatible is more important than ever before. ${ }^{5}$ Improving the management practices of soil- cropwater to improve soil quality, soil fertility, land productivity and ultimately food security and sustainable agriculture while ensure the conservation of natural resources. Improved soil management practices for economic, social and environmental sustainability require better management of soil-crop-water:

i. Soil management and conservation for sustainable agriculture and environment. Soil management and conservation help combat
Volume 3 Issue 3 - 2016

\author{
MMR Jahangir \\ Department of Soil Science, Bangladesh Agricultural University, \\ Bangladesh
}

Correspondence: MMR Jahangir, Department of Soil

Science, Bangladesh Agricultural University, Mymensingh-2202, Bangladesh, Tel +88 01719648448 ,

Email mmrjahangir@bau.edu.bd

Received: January 18, 2016 | Published: March 16, 2016

desertification, soil erosion, enhancement of soil fertility, soil test based fertilizer recommendation and appropriate measures for soil conservation.

ii. Technologies and practices for sustainable use and management of water in agriculture. This help optimize irrigation systems and enhance crop water productivity and water use efficiency, and

iii. Integrated soil-plant management packages to increase crop productivity in unfavorable environments. ${ }^{6}$

Strategies to reduce emissions of greenhouse gas (GHG) are those that increase the use efficiency of inputs, such as conservation agriculture, organic farming, precision farming and that increase $\mathrm{C}$ stock in soil. ${ }^{3}$ Soil restoration and remediation are also important to global climate change mitigation. While improving soil productivity and advancing food security, soil organic carbon storage in degraded lands can partly offset anthropogenic GHG emissions and improve the environment. Adaptation to climate change can be accelerated through cover cropping or mulch farming, appropriate rotation cycle of crops, agro forestry systems, integrated nutrient management (INM) or integrated plant nutrition systems (IPNS) and soil water conservation. The approach in conjunction with judicious management of soilcrop-water can create positive $\mathrm{C}$ and macro nutrient (nitrogen, $\mathrm{N}$; phosphorus, $\mathrm{P}$; sulphur, $\mathrm{S}$ ) status and micro nutrient ( $\mathrm{Zn}, \mathrm{B}$ etc) status.

World cropland soils are about $1.5 \mathrm{~b}$ ha and have a large capacity to sink carbon. ${ }^{3}$

Management of soil organic $\mathrm{C}$ pool is an important strategy to achieve adaptation to and mitigation of global climate change, ${ }^{7}$ while advancing global food security. ${ }^{8}$ As an important sink of C, crop land soils can be used to mitigate and adapt to global climate change. Similar to crop land soils, forest and grassland soils can also be important for $\mathrm{C}$ sequestration. Increasing the forest coverage has a high potential to enhance the terrestrial $\mathrm{C}$ pool through photosynthesis and humification of part of it in soil total organic C pool. ${ }^{9}$ Soil organic $\mathrm{C}$ sequestration (about $0.55 \times 10^{-9} \mathrm{Pg} \mathrm{C} \mathrm{ha}^{-1} \mathrm{y}^{-1} ;^{10}$ ) depends on crop residue management and recycling of organics, climatic conditions, $\mathrm{N}$ application rate and soil properties. 
Numerous factors affect $\mathrm{C}$ sequestration in forest soils, e.g. $\mathrm{C}$ input by litter and roots into soil profile, soil genesis, $\mathrm{N}$ input, water regime, management, burning and residue management.9,11 McKinsey \& Company ${ }^{12}$ estimated that by 2030, afforestation can mitigate $0.27 \mathrm{Pg} \mathrm{C} \mathrm{yr}^{-1}$; reforestation, $0.38 \mathrm{PgC} \mathrm{yr}^{-1}$ and improved management, $0.08 \mathrm{Pg} \mathrm{Cyr}^{-1}$. Grassland soils cover $2.9 \mathrm{~b}$ ha globally, including $2.0 \mathrm{~b}$ ha under tropical grasslands or savannas and $0.9 \mathrm{~b}$ ha under temperate grasslands. $^{3}$ Fertilization, managed grazing, conversion of degraded cropland and native vegetation to pasture, introducing of leguminous and grass pasture species, fire management and water conservation. ${ }^{1.3}$ Average global $\mathrm{C}$ sequestration in grassland soil is $5.4 \times 10^{-10} \mathrm{Pg} \mathrm{C} \mathrm{ha}^{-1}$ $\mathrm{yr}^{-1} \cdot{ }^{13,14}$

\section{Acknowledgements}

None.

\section{Conflict of interest}

The author declares no conflict of interest.

\section{References}

1. IPCC. Climate change 2014: Synthesis report. In: Intergovernmental Panel on Climate Change. Geneva, Switzerland; 2015. 151 p.

2. Brady NC, Weil RR. The nature and properties of soils. 14th ed. Prentice Hall; 2007.

3. Lal R. Managing soils and ecosystems for mitigating anthropogenic carbon emissions and advancing global food security. Bio Science. 2010;60(9):708-721.
4. Barrios E. Soil biota, ecosystem services and land productivity. Ecological Economics. 2007;64(2):269-285.

5. Lal R. Sequestering carbon and increasing productivity by conservation agriculture. Journal of Soil and Water Conservation. 2015;70(3):56A-62.

6. International Atomic Energy Association (IAEA). Soil and water management and crop nutrition subprogramme of the Joint FAO/IAEA programme of nuclear techniques in food and agriculture; 2015.

7. Hansen J, Sato M, Kharecha P, et al. Target atmospheric $\mathrm{CO}_{2}$ : Where should humanity aim? Open Atmosp Sci J. 2008;2:217-231.

8. Lal R. Soil carbon sequestration impacts on global climate change and food security. Science. 2004;304(5677):1623-1627.

9. Lal R. Forest soils and carbon sequestration. Forest Ecology and Management. 2005;220(1-3):242-258.

10. West TO, WM Post. Soil organic carbon sequestration rates by tillage and crop rotation: A global data analysis. Soil Science Society of America Journal. 2002;66(6):1930-1946.

11. Lal R. Soil carbon sequestration in natural and managed tropical ecosystems. J Sust Forestry. 2005;2:1-30.

12. McKinsey and Company. Pathways to a Low Carbon Economy. Version 2 of the global greenhouse gas abatement cost curve; 2009.

13. Conant RT, Paustian K, Elliott ET. Grassland management and conversion into grassland: Effects on soil carbon. Ecol Appl. 2001;11(2):343-355.

14. Lal R. Societal value of soil carbon. Journal of Soil and Water Conservation. 2014;69(6):186-192A. 